\title{
PERTANGGUNGJAWABAN PIDANA DAN PEMIDANAAN TERHADAP PELAKU PEDOFILIA DALAM HUKUM PIDANA INDONESIA
}

\author{
Oleh : \\ Anak Agung Ayu Sinta Paramita Sari ${ }^{1}$
}

\begin{abstract}
In criminal law there are a criminal act, criminal liability, and criminalization. Criminal liability consept in criminal law is a central concept be known mens rea. Mens rea concept based an act doesn't not result in a person guilty unless the mind is bad. In Indonesian Criminal Code there regulates the negative form of criminal liability, contained in article 44. In article 44 Indonesian criminal code mentions that the mental disorder can be held accountable for criminal liability. Pedophilia is a sexual disorder that possessed by adults who get sexual gratification through physical contact with children. In criminal law pedophilia known as the crime of sexual abuse of minors. There is a vagueness of norms that occurs between article 44 Indonesian criminal code with a court decision regarding pedophilia. Court decision handed down on the accused in this case usually is imprisonment, whereas in the German state people who suffer from pedophilia in rehabilitation by the government. German Criminal Code has arranged the said provisions, this is because the government is aware of the psychological condition of a pedophile. A pedophile will not recover if the punishment given only in the form of imprisonment, without a destination for healing and repair perpetrators later, because criminal punishment should pay attention to the properties or the circumstances of the offender, so that it becomes appropriate punishment and provide benefits to the perpetrator. The research methods used in this paper is a normative legal research methods.
\end{abstract}

\section{Keywords : Pedophilia, Sexual abuse, Criminal liability}

\begin{abstract}
Abstrak
Di dalam hukum pidana terdapat perbuatan pidana, pertanggungjawaban pidana, serta pemidanaan. Konsep pertanggungjawaban dalam hukum pidana merupakan konsep sentral yang dikenal dengan ajaran kesalahan (mens rea). Doktrin mens rea dilandaskan pada suatu perbuatan tidak mengakibatkan seseorang merasa bersalah kecuali jika pikiran orang itu jahat. KUHP Indonesia mengatur mengenai bentuk negatif dari pertanggungjawaban pidana, yang terdapat pada pasal 44 KUHP. Pasal 44 KUHP menyebutkan bahwa orang yang sakit jiwanya serta orang yang mengalami cacat dalam pertumbuhannya tidak dapat dimintai pertanggungjawaban pidana. Pedofilia merupakan suatu penyakit gangguan preferensi seksual yang dimiliki oleh orang dewasa yang mendapatkan kepuasan seksual melalui kontak fisik dengan anak-anak. Di dalam hukum pidana Indonesia pedofilia dikenal sebagai tindak pidana pencabulan anak dibawah

1 Program Studi Magister Ilmu Hukum, Fakultas Hukum Universitas Udayana, Denpasar, Bali, email :sintaparamita.sari@gmail.com
\end{abstract}


umur. Terdapat kekaburan norma yang terjadi antara Pasal 44 KUHP dengan putusan pengadilan mengenai kasus ini. Putusan yang dijatuhkan pada terdakwa dalam kasus ini biasanya adalah hukuman penjara, sedangkan di Negara Jerman orang yang mengidap pedofilia direhabilitasi oleh Pemerintah. Kitab UndangUndang Hukum Pidana Jerman telah mengatur mengenai ketentuan tersebut, hal ini dikarenakan Pemerintah sadar akan kondisi kejiwaan dari seorang pedofilia. Seorang pedofilia tidak akan sembuh jika hukuman yang diberikan hanya berupa kurungan penjara, tanpa ada tujuan untuk penyembuhan dan perbaikan pelaku di kemudian hari, karena seharusnya penjatuhan pidana memperhatikan sifatsifat atau keadaan-keadaan pelaku sehingga pemidanaan itu menjadi tepat dan memberikan manfaat bagi pelaku. Metode penelitian yang digunakan dalam tulisan ini adalah metode penelitian hukum normatif.

\section{Keyword : Pedofilia, Kekerasan Sexual, Pertanggungjawaban Pidana}

\section{PENDAHULUAN}

Hukum pidana memiliki komponen sentral di dalamnya yang membedakan hukum pidana dengan hukum lainnya, yaitu perbuatan pidana, pertanggungjawaban pidana, serta pemidanaan. Pengertian perbuatan pidana tidak termasuk pengertian pertanggungjawaban pidana.Perbuatan pidana hanya menunjuk kepada dilarang dan diancamnya perbuatan dengan suatu ancaman pidana. Apakah orang yang melakukan perbuatan yang dilarang kemudian dijatuhi pidana tergantung kepada apakah dalam melakukan perbuatan itu orang tersebut memiliki kesalahan. ${ }^{2}$ Apabila ia memiliki kesalahan, maka ia dapat dimintai pertanggungjawaban pidana.

Hukum pidana memberikan konsep pertanggungjawaban sebagai konsep sentral yang dikenal dengan ajaran kesalahan (mens rea). Doktrin mens rea dilandaskan pada suatu perbuatan tidak mengakibatkan

2 Moeljatno, 2008, Asas-Asas Hukum Pidana, Cetakan VIII, Jakarta,Rineka Cipta, hlm. 165. seseorang merasa bersalah kecuali jika pikiran orang itu jahat. Berdasarkan asas tersebut, terdapat dua syarat yang harus dipenuhi untuk dapat di pidananya seseorang, yaitu adanya perbuatan lahiriah yang terlarang atau perbuatan pidana (actus reus), dan sikap batin jahat atau tercela (mens rea). ${ }^{3}$

Pertanggungjawaban pidana dalamhukumpidanamengenalduajenis kesalahan, yaitu kesalahan normatif dan kesalahan psikologis. Berkaitan dengan hal ini, Kitab Undang-Undang Hukum Pidana (KUHP) di dalam Pasal 44 mengatur mengenai bentuk negatif dari kemampuan bertanggungjawab seseorang. Dalam perkembangan ilmu pengetahuan saat ini, banyak unsur yang dapat menjadi aspek pertimbangan di dalam menentukan kemampuan bertanggungjawab seseorang. Salah satunya adalah faktor psikologis seseorang. Kasus-kasus

\footnotetext{
3 Hanafi, 1999, Reformasi Sistem Pertanggungjawaban Pidana, Vol. 6, Jurnal Hukum, hlm. 27.
} 
kejahatan yang saat ini ramai terjadi bukan lagi kasus-kasus konvensional seperti dulu. Ilmu pengetahuan serta teknologi yang berkembang pesat saat ini menuntut setiap orang harus pandai dalam mengklasifikasikan suatu kasus yang terjadi.

Salah satu hal yang patut untuk diperhatikan akhir-akhir ini adalah tentang gangguan preferensi seksual merupakan salah satu kasus yang sedang menjadi sorotan di dalam hukum pidana. Orang yang mengidap gangguan preferensi seksual tidak hanya mengalami perilaku yang abnormal, tetapi juga mengalami kelainan dalam orientasi seksual. Penderita yang mengidap gangguan preferensi seksual sangat mungkin akan melakukan tindakan-tindakan yang melanggar hukum, dan hal ini akan menimbulkan keresahan di dalam masyarakat.

Pedofilia adalah suatu penyakit gangguan preferensi seksual yang dimiliki oleh orang dewasa yang mendapatkan kepuasan seksual melalui kontak fisik dengan anak-anak. Anakanak yang menjadi objek dari seorang yang mengidap pedofilia biasanya adalah anak-anak prapubertas dan yang tidak memiliki hubungan darah dengannya. Orang yang mengidap pedofilia biasanya tidak melakukan kekerasan di dalam tindak pidana asusila yang ia lakukan dengan anak di bawah umur. Akan tetapitidak menutup kemungkinan seorang pedofilia akan melakukan tindak pidana lain seperti pengancaman, kekerasan, bahkan sampai dengan pembunuhan untuk mendapatkan kepuasan seksual yang berkaitan dengan gangguan preferensi seksual yang ia miliki. Karena beberapa orang yang mengidap pedofilia mencari pasangan tidak begitu saja menurutinya atau dengan melanggar hak orang lain, maka gangguan ini sering memiliki konsekuensi hukum. ${ }^{4}$

Hukum pidana mengenal pedofilia sebagai tindak pidana pencabulan anak di bawah umur. Hukum pidana Indonesia melihat orang yang mengidap pedofilia adalah sebagai layaknya orang normal yang memiliki kemampuan bertanggungjawab pada tindak pidana yang ia lakukan, sehingga dalam setiap putusan mengenai kasus pedofilia para pelakunya dijatuhi pidana penjara. Sementara itu dalam ilmu kedokteran jiwa pedofilia merupakan suatu penyakitkejiwaandimanapenderitanya mengalami gangguan preferensi seksual dengan objek seksual yang tidak wajar yaitu anak-anak dibawah umur. Sehingga jika dikaitkan dengan alasan pemaaf terkait dengan Pasal 44 KUHP yang menyebutkan bahwa orang yang mengalami gangguan jiwa, atau cacat jiwanya tidak dapat mempertanggungjawabkan perbuatan pidana yang dilakukannya.

Kesenjangan yang terjadi antara KUHP dengan fakta yang terjadi saat

4 Gerald C. Davison, John M. Neale, dan Ann M. Kring, 2010, Psikologi Abnormal, Edisi Ke-9, Cetakan Ke-2, Jakarta, Rajawali Pers, hlm. 623. 
ini, menimbulkan adanya kekaburan norma dimana tidak terdapat penjelasan lebih rinci mengenai apa yang dimaksud di dalam Pasal 44 KUHP berkaitan dengan orang yang sakit jiwanya serta orang yang mengalami cacat dalam pertumbuhannya. Tidak terdapat penjelasan pasti tentang keadaan-keadaan seperti apa yang dapat dikualifikasikan dalam Pasal 44 KUHP, sehingga diperlukan penafsiran lebih lanjut mengenai konsep yang terkandung dalam Pasal 44 KUHP ini. Kekaburan norma ini kemudian berdampak pada hasil putusan-putusan yang dijatuhkan oleh hakim berkaitan dengan kasus pedofilia. Beberapa putusan mengenai kasus pedofilia di Indonesia setiap pelaku pedofilia selalu dipidana, sesuai ketentuan Pasal 290 ayat (2) dan (3), Pasal 292, dan Pasal 293 ayat (1) KUHP jo Pasal 82 Undang-Undang Nomor 23 Tahun 2002 tentang Perlindungan Anak.

Fokus kajian dalam tulisan ini membahas permasalahan sebagai berikut :

1. Bagaimana pertanggungjawaban pidana seseorang yang mengidap pedofilia dalam hukum pidana Indonesia?

2. Bagaimana pemidanaan bagi seseorang yang mengidap pedofilia di Indonesia?

Orisinalitas jurnal ilmiah merupakan hal yang penting, karena dari penjabaran beberapa jurnal yang telah diterbitkan sebelumnya dengan permasalahan yang sama, akan terlihat perbandingan tulisan yang kita tulis, sebagai indicator orisinalitas karya tulisan ilmiah yang kita tulis. Berikut adalah beberapa jurnal ilmiah terkait mengenai pedofilia.

Gede Arya Suputra, Kajian Teoritis Terhadap Tindak Pidana Pedofilia di Indonesia, Kesimpulan:(1) Bahwa tindak pidana pedofilia secara eksplisit tidak diatur dalam hukum Indonesia tetapi hal ini bukan berarti para hakim hanya membiarkan para pelaku tersebut dikarenakan adanya asas legalitas serta adanya Pasal demi Pasal yang masih berkenaan dengan pedofil sesuai dengan pengertian pedofil itu sendiri. Seperti makna dari pedofil sendiri yaitu melakukan pelecehan seksual terhadap anak dibawah umur, dan anak itu sendiri dilindungi dari tindakan eksploitasi seksual maka hal tersebut sama halnya dengan yang terdapat dalam Pasal 82 Undang-Undang Nomor 23 Tahun 2002 yaitu :", Setiap orang-orang yang dengan sengaja melakukan kekerasan atau ancaman kekerasan, memaksa, melakukan tipu muslihat, serangkaian kebohongan, atau membujuk anak untuk melakukan atau membiarkan dilakukannya perbuatan cabul, dipidana dengan pidana penjara paling lama 15 (lima belas) tahun dan paling singkat 3 (tiga) tahun dengan denda paling banyak $R p$. 300.000.000,00 (tiga ratus juta rupiah) dan paling sedikit Rp. 60.000.000,00 (enam puluh juta rupiah)". (2) Bahwa dalam meminimalisir terjadinya 
pertambahan korban terhadap tindak pidana ini perlu dilakukan suatu revisi dan tambahan-tambahan Pasal dengan uraian yang jelas terhadap tindak pidana pedofilia dan hukuman yang lebih berat agar tercapainya tujuan dari hukuman tersebut yaitu menciptakan efek jerah dan bila mana tidak bisa mengakibatkan efek jerah, sepatutnya di tambahkan suatu hukuman seperti hukuman pengrehabilitasian yang khusus bagi para pelaku maupun korban.

Agne Nia Dara, Analisis Putusan Pengadilan Negeri Singaraja Bali Nomor 292/ Pid.Sus/2012/Pn.Sgr. Terkait Perlindungan Bagi Anak Korban Tindak Pidana Pedofilia Di Indonesia, Kesimpulan :

(1) Perlindungan bagi anak korban Tindak Pidana Pedofilia dalam Proses Peradilan Pidana di Putusan Pengadilan Negeri Singaraja Bali Nomor 292/ Pid.Sus/2012/PN.SGR adalah sebagai berikut:

a. Pada Tahap Penyidikan

- Polisi dan Lembaga Swadaya Masyarakat melakukan penjemputan anak korban guna kepentingan penyidikan.

- Anak Korban diperiksa di Unit Perlindungan Perempuan dan Anak.

- Penyidikan dilakukan oleh Polisi Wanita.

- $\quad$ Pada tahap penyidikan anak korban didampingi oleh Orang tua.
- Didampingi oleh Komisi Perlindungan Anak dan Perempuan.

- Didampingi oleh Lembaga Swadaya Masyarakat.

b. Pada tahap Persidangan

- Anak Saksi tidak disumpah.

- Penderitaan yang dialami oleh anak korban adalah sebagai dasar yang memberatkan bagi pertimbangan hakim.

- Majelis Hakim Menjatuhkan Saksi Pidana Penjara terhadap Terdakwa Tindak Pidana Pedofilia karena terbukti melakukan tindak pidana sebagaimana diatur dan diancam pidana dalam Pasal 82 UndangUndang Nomor 23 Tahun 2002 tentang Perlindungan Anak.

(2) Perlindungan Anak Korban Tindak Pidana Pedofilia pada Putusan Pengadilan Negeri Singaraja Bali Nomor 292/ Pid. Sus/2012/PN.SGR. Menurut Harapan Undang-Undang No. 35 Tahun 2014 tentang Perubahan Undang-Undang No 23 Tahun 2002 tentang Perlindungan Anak yakni:

a. Edukasi tentang Kesehatan Reproduksi, Nilai Agama dan Nilaikesusilaan. Karena Putusan hukum yang dahulu belum terdapat Undang- 
Undang yang mewajibkan maka formulasi yang disesuaikan.

b. Rehabilitasi Sosial. Tidak terdapat putusan hakim yang memberikan upaya rehabilitasi sehingga

Rehabilitasi Sosial tidak terpenuhi.

c. Pendampingan Psikososial Pada Saat Pengobatan Sampai Pemulihan, karena Putusan hukum yang dahulu belum terdapat UndangUndang yang mewajibkan maka formulasi yang disesuaikan.

d. Pemberian Perlindungan dan Pendampingan pada Setiap Tingkat Pemeriksaan Mulai dari Penyidikan, Penuntutan, Sampai Dengan Pemeriksaan di Sidang Pengadilan. Seluruh saksi melakukan pencabutan keterangan Berita Acara Pemeriksaan. Maka jelas bahwa saksi korban tidak mendapatkan jaminan perlindungan bagi baik fisik, mental, maupun sosial.

Junita B. Mokale, Pedofilia Sebagai Salah Satu Bentuk Kejahatan Kekerasan Seksual Terhadap Anak, Kesimpulan : (1) Pedofilia merupakan aktivitas perilaku penyimpangan dengan menggunakan pencabulan anak untuk memperoleh kepuasan seksual atau mengekspresikan kepentingan seksualnya. Penegakan hukum pidana untuk menanggulangi pedofilia sebagai perilaku yang menyimpang harus terus dilakukan karena pedofilia merupakan ancaman yang nyata terhadap normanorma sosial yang dapat menimbulkan ketegangan individual maupun ketegangan-ketegangan sosial. Pedofilia merupakan ancaman riil atau potensial bagi berlangsungnya ketertiban sosial. Upaya hukum pidana dalam menanggulangi kejahatan pedofilia masih menggunakan KUHP sebagai dasar untuk melakukan pemidanaan terhadap pelaku/pembuat walaupun Undang-Undang No. 23 Tahun 2002 tentang Perlindungan Anak telah diterbitkan. Hal ini dikarenakan peraturan perundangundangan tersebut tidak membuat peraturan atau ketentuan yang bersifat khusus atau menyimpang dari KUHP. (2) Kebijakan formulasi hukum pidana dalam menanggulangi kejahatan pedofilia di masa yang akan datang sudah termuat secara khusus pada Buku II sub bab tentang Perkosaan dan Perbuatan Cabul Pasal 489 sampai dengan Pasal 498 Konsep KUHP.

Tujuan dari penelitian ini adalah untuk mengetahui bagaimana hukum pidana Indonesia dalam memberikan kualifikasipertanggungjawaban pidana terhadap seorang yang mengidap pedofilia, dan untuk mengetahui bentuk pemidanaan seperti apa yang dijatuhkan kepada seorang yang mengidap pedofilia. Serta tujuan apa 
yang ingin dicapai oleh hukum pidana Indonesia dengan pidana yang telah dijatuhkan kepada pelaku pedofilia.

\section{METODE PENELITIAN}

Jenis penelitian yang digunakan dalam tulisan ini adalah penelitian hukum normatif. Penelitian hukum normatif membahas doktrin-doktrin atau asas-asas dalam ilmu hukum. Teknik pengumpulan bahan hukum yang dipergunakan adalah dengan menggunakan sistem kartu. Yang dimaksud dengan sistem kartu adalah setelah mendapat semua bahan yang diperlukan, kemudian dibuat catatan mengenai hal-hal yang dianggap penting bagi penelitian yang dilakukan. $^{5}$

III. HASIL DAN PEMBAHASAN 3.1 Pertanggungjawaban Pidana Pelaku Pedofilia di Indonesia

Pedofilia adalah gangguan preferensi seksual dimana orang dewasa mendapatkan kepuasan seksual melalui kontak fisik dengan anak-anak prapubertas atau bahkan anak-anak pasca pubertas yang tidak memiliki hubungan darah dengan mereka. Gangguan kejiwaan ini sering sekali berujung pada suatu kejahatan atau tindak pidana, dimana sangat mungkin bagi penderita pedofilia untuk melakukan tindak pidana yang berkaitan dengan penyakit kejiwaan yang ia derita. Tindak pidana yang

5 Soerjono Soekanto dan Sri Mamudji, 2007, Penelitian Hukum Normatif, Jakarta, PT Raja Grafindo Persada, hlm. 52. terkait dengan orang yang mengidap pedofilia di Indonesia dikategorikan sebagai tindak pidana asusila (pencabulan terhadap anak di bawah umur).

Ajaran kesalahan menyebutkan terdapat dua jenis teori kesalahan, yaitu teori kesalahan normatif dan teori kesalahan psikologis. Dalam praktik teori kesalahan yang lebih sering digunakan adalah teori kesalahan normatif, karena teori ini lebih mudah dijelaskan, dan memiliki kepastian dibandingkan teori kesalahan psikologis karena teori kesalahan psikologis berkaitan dengan psikologis atau keadaan batin seseorang dengan perbuatan yang ia lakukan. Dikaitkan dengan pertanggungjawaban pidana, menurut teori kesalahan normatif terdapat tiga hal dasar dalam menentukan kesalahan, yaitu:

1. Dapat dicela

Dapat dicela di sini terdapat dua arti dimana arti yang pertama adalah dapat dipertanggungjawabkan dalam hukum pidana, dan arti yang kedua adalah dapat dijatuhi pidana. Dalam menentukan kesalahan arti yang pertama yang dipergunakan, karena kata 'dapat' di sini menunjukkan bahwa celaan atau pertanggungjawaban itu hilang jika pembuat memiliki alasan penghapus kesalahan.

Alasan penghapus kesalahan merupakan alasan-alasan yang dapat membuat diri si pembuat tidak dapat bertanggungjawab secara keseluruhan atau dapat bertanggungjawab untuk 
sebagian atas perbuatan pidana yang ia lakukan. Alasan-alasan ini ada yang terdapat di dalam diri pembuat atau di luar diri pembuat. Sebagian besar KUHP di dunia termasuk di Indonesia hanya menyebutkan bentuk negatif dari pertanggungjawaban pidana.

Tidak disebutkan lebih jauh mengenai keadaan-keadaan seperti apa orang tidak mampu bertanggungjawab untuk keseluruhan, maupun untuk sebagian. Sesungguhnya hal ini penting karena pertanggungjawaban pidana terkait dengan pemidanaan seseorang. Dalam Pasal 44 KUHP diatur mengenai bentuk negatif dari pertanggungjawaban pidana, yang mana dalam bunyi Pasal 44 menyebutkan bahwa orang yang melakukan suatu perbuatan pidana karena cacat jiwanya dalam pertumbuhan atau terganggu karena penyakit tidak dipidana. Penjelasan lebih lanjut mengenai bunyi Pasal ini tidak disebutkan. Maka tidak ada pandangan serta konsep yang jelas apa yang dimaksud dengan cacat jiwanya, dan keadaan-keadaan seperti apa yang dapat dikategorikan sebagai cacat jiwanya atau terganggu karena penyakit.

2. Dilihat dari segi masyarakat

Unsur ini bertitik tolak terhadap subjek hukum manusia, pengertian kesalahan yang normatif berpangkal tolak pada penilaian hukum terhadap psikologis pembuat. Aspek yang penting dalam unsur ini adalah penilaian normatif terhadap psikologis pembuat, ketika melakukan tindak pidana. Penilaian terhadap normanorma hukum pidana ini ditujukan atas perbuatan, pembuat dan hubungan antara keduanya.

Uraiankasus diatasapabiladilihat dari sudut pandang ilmu psikiatri, pencabulan terhadap anak dibawah umur merupakan suatu penyakit psikologis abnormal. Penyimpangan fantasi seksual yang tidak wajar yang dimiliki oleh si penderita, yang mana jika ketertarikannya kepada anak-anak maka penyimpangan ini disebut pedofilia. Sedangkan dalam hukum pidana tidak mengenal istilah pedofilia, istilah yang dipergunakan adalah pencabulan terhadap anak dibawah umur. Dilihat dari sudut pembuat, perbuatan dan hubungan antara keduanya terdapat suatu pola, yaitu pembuat dalam hal ini adalah para terdakwa, merupakan orang dewasa yang melakukan persetubuhan atau pencabulan terhadap anak dibawah umur.

Pembuat di sini melakukan perbuatan terhadap korban. Kemudian perbuatan, perbuatan pidana yang dilakukan oleh para terdakwa merupakan suatu kejahatan yang sudah diatur secara normatif oleh hukum pidana. Hubungan antara keduanya di sini lebih banyak dipusatkan pada keadaan batin pembuat dan tindak pidana yang dilakukannya. Pada setiap kasus masing-masing terdakwa memiliki cara berbeda dalam melakukan perbuatannya, tetapi 
keadaan batin para terdakwa pada saat melakukan tindak pidana pencabulan tersebut adalah salah. Dalam arti terdakwa telah merencanakan terlebih dahulu untuk mencabuli korbannya, melakukan usaha-usaha seperti tipu muslihat, kebohongan, paksaan atau ancaman terhadap korban sebelum melakukan perbuatan cabul. Seperti yang telah diuraikan diatas dalam doktrin mens rea dilandaskan pada perbuatan tidak mengakibatkan orang itu bersalah kecuali pikiran orang itu jahat. Dalam pikiran terdakwa sudah ada niat jahat untuk melakukan pencabulan, maka dengan demikian terjadilah serangkaian perbuatanperbuatan yang menjadi langkah awal dalam tindak pidana pencabulan tersebut.

3. Dapat berbuat lain

Yang dimaksud dalam pengertian ini adalah selalu ada kesempatan bagi pembuat untuk menghindari terjadinya perbuatan pidana, dalam arti yang sebenarnya pembuat dapat berbuat lain jika tidak ingin melakukan perbuatan pidana. Inti pengertian kesalahan dalam penilaian hukum pidana terletak pada bahwa pembuat dapat berbuat lain, ketiadaan lain selain pembuat melakukan tindak pidana menyebabkan pembuat dapat dilepaskan dari keadaan bersalah.

Dilihat dari sudut psikologis para terdakwa dalam kasus diatas memiliki nalar yang sehat, serta dapat berpikir dengan baik. Dengan demikian seharusnya pembuat dapat berbuat hal lain jika ia tidak menginginkan tindak pidana pencabulan itu terjadi. Lain halnya jika seorang pedofilia mengalami kegagalan untuk menolak hasrat seksual yang datang padanya tiba-tiba yang pada akhirnya membuat ia melakukan tindak pidana pencabulan, seperti halnya orang dengan kleptomania. Orang dengan kleptomania melakukan tindak pidana pencurian karena sebelumnya ia telah gagal untuk menolak rekuen impuls yang datang padanya untuk mengambil barang-barang milik orang lain. Padahal barang-barang tersebut mampu ia beli sendiri dan tidak memiliki nilai ekonomi baginya, karena seorang dengan kleptomania tidak dapat berbuat lain maka, ketika ia melakukan tindak pidana pencurian, ia dibebaskan dari keadaan bersalah, dengan syarat pada saat ia melakukan tindak pidana itu ia terlebih dahulu telah gagal dalam menolak rekuen impuls yang datang secara tiba-tiba padanya, pencurian itu bukan direncanakan, dan barang-barang yang dicuri tidak boleh memiliki nilai ekonomis maupun kemanfaatan.

Meskipun demikian hukum pidana harus melihat bahwa terdapat faktoryangmelatarbelakangiterjadinya perbuatan cabul yang dilakukan terhadap anak dibawah umur tersebut. Hukum pidana melupakan bahwa orang yang melakukan suatu tindak pidana pencabulan terhadap anak dibawah umur adalah merupakan orang dengan kelainan orientasi seksual. Gangguan 
preferensi seksual ini sudah termasuk kedalam ranah disiplin ilmu lain, yang mana diperlukan pertolongan pada saksi ahli di bidang ini. Pertolongan saksi ahli di sini adalah untuk memberikan pendapat serta saran yang jelas mengenai kesehatan psikologis terdakwa karena memiliki orientasi seksual menyimpang, yaitu pada anakanak. Serta apakah ada hubungannya gangguan preferensi seksual yang ada pada terdakwa dengan perbuatan pidana yang ia lakukan terhadap anak dibawah umur. Untuk dapat memberikan pendapat serta saran, saksi ahli harus diberikan kesempatan untuk memeriksa terdakwa secara mendalam, dan hal ini dapat menjadi bahan pertimbangan oleh hakim dalam menjatuhkan pidana dikaitkan dengan Pasal 44 KUHP.

Di Negara Jerman terdapat perbedaan yang mendasar antara sistem hukum pidana Indonesia dengan sistem hukum Negara lain (dalam hal ini Negara Jerman) dalam melihat kasus pelecehan seksual terhadap anak-anak serta sistem hukum pidana melihat pelaku tindak pidana ini. Seperti yang telah diuraikan sebelumnya hukum pidana melihat pelaku tindak pidana pelecehan seksual terhadap anak sebagai orang normal yang memiliki akal serta nalar yang baik, serta dapat membedakan antara baik dan buruk maka dari itu hukum pidana Indonesia menilai pelaku pedofilia memiliki kemampuan bertanggungjawab penuh dalam tindak pidana pelecehan seksual terhadap anak yang dilakukannya.
Hukum pidana Indonesia dalam Pasal 44 KUHP mengkualifikasikan orang-orang yang tidak dapat bertanggungjawab adalah orang-orang yang hilang akal (orang gila), orang idiot, serta orang yang mengidap penyakit epilepsy. Rumusan Pasal 44 KUHP juga tidak menyebutkan serta memberikan definisi yang jelas mengenai apa yang dimaksud dengan cacat jiwanya dan cacat dalam pertumbuhannyakarenasuatupenyakit. Ketidakjelasan ini menjadikan aparat penegak hukum tidak dapat memberikan sanksi yang tepat kepada pelaku tindak pidana, karena pedoman yang mereka pergunakan tidak memberikan penjelasan yang rinci.

Perbedaan

kemampuan

bertanggungjawab seseorang akan berakibat pada penjatuhan sanksi yang berbeda juga terhadap orang tersebut. Oleh karena hukum pidana Indonesia melihat pelaku tindak pidana pencabulan adalah selayaknya orang normal padaumumnyayang melakukan suatu perbuatan yang dilarang oleh Undang-undang, maka dari itu sebagai reaksi dari apa yang sudah ia lakukan, hukum pidana hanya memberikan hukuman sesuai ketentuan perundangundangan yang berlaku baik itu pidana penjara ataupun ditambah dengan pidana denda. Akan tetapi ada hal mendasar yang dilupakan oleh hukum pidana Indonesia dalam melihat kasus pedofilia, orang yang mengidap pedofilia terlihat normal karena sakit yang ia derita merupakan sakit psikis 
dimana ia memiliki orientasi seksual yang menyimpang, yaitu pada anakanak di bawah umur. Orang dengan pedofil tidak saja serta-merta akan jera terlebih lagi sembuh dan tidak mengulangi lagi perbuatannya apabila ia di penjara selama sekian tahun. Orang dengan gangguan kejiwaan seperti ini harus dilakukan perbaikan pada dirinya agar ia dapat sembuh dari penyakitnya dan memiliki orientasi seksual yang normal. Merupakan pandangan yang salah apabila menganggap orang yang mengidap pedofilia setelah di penjara tidak akan mengulangi perbuatannya lagi. Orang yang sakit jika hanya diberi hukuman tetapi tidak diberikan obat untuk menyembuhkan penyakitnya, maka sakit yang ia derita tidak akan pernah sembuh.

Paradigma seperti ini dalam sistem hukum pidana Indonesia harus segera diubah. Dapat kita lihat sebagai bahan perbandingan di dalam sistem hukum Jerman melihat pelaku kasus pedofilia, para pelakunya dimasukkan ke rumah sakit jiwa guna mendapatkan pengobatan, perawatan, dan rehabilitasi. Hal ini dilakukan karena pemerintah, dan aparat penegak hukum sadar bahwa orang dengan pedofilia merupakan orang dengan gangguan kejiwaan yang harus diperbaiki jika menginginkan kelak ia tidak akan melakukan hal yang sama atau bahkan yang lebih buruk lagi.

Kesadaran Pemerintah Jerman dalam melihat pertanggungjawaban pelakukasuspedofiliasudahdituangkan di dalam German Criminal Code, dimana pada Pasal 63 menyebutkan:

Article 63 of the Criminal Code provides that if someone commits an unlawful act without criminal responsibility pursuant to Article 20, the court orders their placement without maximum duration in a psychiatric hospital if a comprehensive evaluation of the defendant and his act reveals that as a result of his condition he can be expected to commit serious unlawful acts and that he therefore dangerous to the general public.

(Terjemahan bebas penulis)

Pasal 63 Kitab Undang-Undang Hukum Pidana menetapkan apabila seseorang melakukan perbuatan melanggar hukum tanpa memiliki kemampuan bertanggungjawab menurut Pasal 20, pengadilan memerintahkan untuk menepatkan mereka tanpa tenggang waktu yang ditentukan di rumah sakit jiwa, apabila penilaian secara keseluruhan dari terdakwadanmenyatakanperbuatannya itu merupakan hasil dari keadaannya ia dapat disangka melakukan perbuatan melanggar hukum yang serius dan bahwa karena itu dia dinilai berbahaya bagi masyarakat umum.

Hukum pidana Jerman dalam Pasal20Kitab Undang-Undang Hukum Pidana Jerman juga memberikan kualifikasi keadaan orang yang tidak dapat bertanggungjawab pidana, yang salah satu diantaranya orang yang mengidap pedofilia. 
Pursuant to Article 20 of the German Criminal Code, a person who upon commission of a criminal offence is incapable of appreciating the wrongfulness of the act or of acting in accordance with such appreciation due to pathological emotional disorder, profound personality disorder, mental defect or any other serious emotional abnormality, acts without guilt.

(Terjemahan bebas penulis)

Menurut Pasal 20 Kitab UndangUndang Hukum Pidana Jerman orang yang melakukan perbuatan pidana (delik) tidak mampu untuk menilai kesalahan dari tindakan atau perbuatannya sesuai dengan pengetahuan tersebut karena gangguan emosional patologis, gangguan kepribadian mendalam, cacat mental atau kelainan emosional serius lainnya, tindakan tersebut dilakukan tanpa kesalahan.

Konsistensi sistem hukum pidana Jerman dalam kasus pedofilia terlihat meski kejahatan pedofilia telah terungkap pada tahun 1980an tetapi sampai saat ini para pelaku yang memang belum dianggap sembuh tidak dibebaskan dari rumah sakit jiwa tempat mereka ditahan. Proses hukum tetap berjalan tetapi di sisi lain proses penyembuhan terdakwa juga tetap diberikan. Seperti yang telah dipaparkan sebelumnya pada kasus pedofilia hukum pidana tidak dapat berdiri sendiri karena kasus pedofilia melibatkan disiplin ilmu lain yaitu ilmu psikologi dan ilmu kejiwaan, maka dari itu sudah seharusnya dalam penyelesaian kasus pedofilia melibatkan para ahli di bidang tersebut seperti yang dilakukan di Jerman, akan tetapi di Indonesia hal itu sepertinya dilupakan oleh aparat penegak hukum.

\subsection{Pemidanaan Terhadap Pelaku Pedofilia}

Pemidanaan dapat diartikan sebagai suatu reaksi atas suatu tindak pidana. Pemidanaan berwujud suatu nestapa atau kesengsaraan yang sengaja diberikan oleh Negara kepada pelaku tindak pidana. Penjatuhan pidana penjara bagi para terdakwa hanyalah memberi rasa puas bagi pihak korban ataupun masyarakat yang merasa dirugikan, tidak ada upaya perbaikan di dalam penjatuhan pidana tersebut. Seperti yang telah diuraikan sebelumnya, orang yang melakukan perbuatan cabul terhadap anak dibawah umur merupakan orang dengan gangguan preferensi seksual dimana orang tersebut menderita sakit psikis yang tidak dapat disembuhkan denganjalan penjatuhan pidana penjara saja. Hal ini yang belum disadari dalam konsep hukum pidana Indonesia.

Konsep pemidanaan dalam hukum pidana Indonesia terkait dengan kasus pedofilia belum sampai kepada tahap bahwa pemidanaan yang diberikan harus dapat memperbaiki terpidana agar pemidanaan yang diberikan tidak sia-sia. Seperti di dalam Kitab Undang-Undang 
Hukum Pidana Jerman, di sana sudah dituangkan konsep mengenai correction (perbaikan) dan prevention measures (upaya pencegahan), sehingga pemidanaan yang diberikan kepada pelaku pedofilia adalah rehabilitasi di rumah sakit jiwa meski pada awalnya atau pada akhirnya pelaku juga dijatuhi pidana penjara untuk menimbulkan efek jera. Tetapi hal yang terpenting yang patut kita lihat di sini ialah kesadaran akan orang dengan pedofilia ini memang tidak dapat hanya dihukum di dalam penjara saja. Orang dengan penyakit kejiwaan seperti ini memang harus mendapatkan pengobatan, perawatan, serta rehabilitasi untuk menyembuhkan sakit psikis yang ia derita. Bahkan di Jerman tidak ditentukan batas waktu maksimum seseorang yang mengalami gangguan kejiwaan untuk berada di rumah sakit jiwa. Di sini terlihat jelas konsistensi hukum pidana Jerman dalam memperbaiki terpidana agar tidak melakukan kesalahan yang sama di kemudian hari, dengan demikian maka pemidanaan yang dijatuhkan memiliki manfaat tidak hanya bagi pelaku, tetapi juga pada masyarakat umum.

Jenis tipe pemidanaan absolute yang dijatuhkan pada terdakwa dalam kasus pedofilia kurang tepat, karena pelaku dengan pedofilia tidak memerlukan pembalasan, karena tidak ada yang dapat menjamin bahwa seorang pedofilia setelah menjalani hukuman penjara dan kemudian bebas tidak akan melakukan perbuatan yang sama lagi, atau bahkan perbuatan yang lebih buruk dari yang sebelumnya. Oleh karena itu pelaku dengan pedofilia memerlukan pengobatan, serta perawatan untuk memperbaiki dirinya dan mengembalikan orientasi seksualnya selayaknya orang normal lainnya. Seharusnya penjatuhan pidana harus memperhatikan sifatsifat atau keadaan-keadaan pelaku sehingga pemidanaan itu menjadi tepat dan memberikan manfaat bagi pelaku (Individualisasi Pidana).

\section{KESIMPULAN}

1. Bahwa hukum pidana Indonesia mengkualifikasikan orang yang mengidap pedofilia sebagai orang yang memilikikemampuan bertanggungjawab atas tindak pidana yang dilakukannya. Tanpa memperhatikan keberadaan pasal 44 KUHP sebagai pedoman di dalam melihat kemampuan bertanggungjawab seseorang berkaitan dengan penyakit kejiwaan pada orang yang mengidap pedofilia. Hal ini berbeda dengan Negara lain (dalam hal ini adalah Negara Jerman).

2. Bahwa pemidanaan yang dijatuhkan pada orang yang mengidap pedofilia di Indonesia masih kurang tepat. Penjatuhan pidana kepada seseorang haruslah melihat sifat-sifat dan keadaan-keadaan pelaku, karena 
kejahatan merupakan kenyataan sosial dan sebagai perbuatan manusia sehingga tidak cukup selesai dengan merumuskan perbuatan tersebut serta memberi sanksi sesuai dengan Undangundang yang berlaku, masih diperlukan adanya pemahaman terhadap kejahatan tersebut serta upaya penanggulangannya.

\section{DAFTAR PUSTAKA}

Gerald C. Davison, John M. Neale, dan Ann M. Kring, 2010, Psikologi Abnormal, Edisi Ke-9, Cetakan Ke-2, Rajawali Pers, Jakarta.

Hanafi, 1999, Reformasi Sistem Pertanggungjawaban Pidana, Vol. 6, Jurnal Hukum.

Moeljatno, 2008, Asas-Asas Hukum Pidana, Cetakan VIII, Rineka Cipta, Jakarta.

Soerjono Soekanto dan Sri Mamudji, 2007, Penelitian Hukum Normatif, PT Raja Grafindo Persada, Jakarta. 